\title{
TRAINING MANAJEMEN KEUANGAN DAN PEMBUKUAN PRAKTIS BAGI PELAKU USAHA MIKRO KECIL MENENGAH DI KELURAHAN MAMBOK KABUPATEN SINTANG
}

\author{
Emilia Dewiwati Pelipa, Anna Marganingsih \\ STKIP Persada Khatulistiwa \\ pelipaemilia@stkippersada.ac.id, amargningsih@gmail.com
}

\begin{abstract}
The development of micro, small and medium enterprises (SMEs) attracted the attention of various parties, both government and businesses. In the city of Sintang, the growth of micro small and medium enterprises is growing very rapidly with the type of business sector that is cultivated also varies, but there are still many micro, small and medium enterprises that have not implemented financial management and bookkeeping on the business they run. Good management and bookkeeping are also the basis of valuation for investors in investing for small businesses to generate greater profits; for it is deemed necessary to provide Training on Financial Management and Practical Bookkeeping for Micro, Small and Medium Enterprises to the perpetrators of SMEs in Mambok district Sintang District. The purpose of this PkM activity to provide contribution for the perpetrators of SMEs in managing good financial management. SMEs actors can make Practical bookkeeping for the business they run Enhance business management skills for the community and create selfemployment based on science and technology. The methods used include survey, implementation of activities and monitoring. The results of this community service activity Participants have been able to formulate long-term and short-term goals that must be achieved in developing their business. Recognizing that the financial record is important for the sustainability of the business going forward. The outcome achieved in this community service activity is the draft journal.
\end{abstract}

Keywords: Financial management, micro small medium enterprise

\begin{abstract}
Abstrak: Pengembangan usaha mikro kecil dan menengah (UMKM) menarik perhatian berbagai pihak, baik dari pemerintah maupun pelaku usaha. Di kota Sintang pertumbuhan usaha mikro kecil menengah berkembang dengan sangat pesat dengan jenis bidang usaha yang digeluti juga bervariasi, namun masih banyak pelaku usaha mikro, kecil dan menengah yang belum menerapkan manajemen keuangan dan pembukuan pada usaha yang dijalankannya. Manajemen yang baik dan kerapian pembukuan juga menjadi dasar penilaian bagi para investor dalam menanamkan modal agar usaha kecil dapat menghasilkan laba yang lebih besar; untuk itu dipandang perlu untuk memberikan Training Manajemen Keuangan dan Pembukuan praktis bagi pelaku Usaha Mikro, Kecil dan Menengah kepada Pelaku UMKM di kelurahan Mambok Kabupaten Sintang. Tujuan dari kegiatan PkM ini untuk memberikan kontibusi bagi pelaku UMKM dalam mengatur Manajemen keuangan yang baik. Pelaku UMKM dapat membuat pembukuan Praktis bagi usaha yang mereka jalankan Meningkatkan keterampilan manajemen usaha bagi masyarakat dan menciptakan wirausaha yang mandiri berbasis Iptek. Metode yang digunakan meliputi survey, pelaksanaan kegiatan dan monitoring. Hasil kegiatan pengabdian kepada masyarakat ini Peserta sudah dapat merumuskan tujuan jangka panjang dan jangka pendek yang harus dicapai dalam mengembangkan usahanya. Menyadari bahwa pencatatan keuangan itu penting untuk keberlangsungan usaha kedepan. Luaran yang dicapai dalam kegiatan pengabdian masyarakat ini adalah draf jurnal.
\end{abstract}

Kata kunci: Manajemen keuangan, usaha mikro kecil menengah

\section{PENDAHULUAN}

Di kota Sintang pertumbuhan usaha mikro kecil menengah berkembang dengan sangat pesat dengan jenis bidang usaha yang digeluti juga bervariasi, namun masih banyak pelaku usaha mikro, kecil dan menengah yang belum 
menerapkan manajemen keuangan dan pembukuan pada usaha yang dijalankannya. Hal ini menjadi faktor penghambat laju perkembangan usaha, karna pemahaman tentang pengelolaan keuangan dan sistem pembukuan yang rapi merupakan nadi dari keberhasilan suatu usaha. Manajemen yang baik dan kerapian pembukuan juga menjadi dasar penilaian bagi para investor dalam menanamkan modal agar usaha kecil dapat menghasilkan laba yang lebih besar.

Selain itu, sistem pencatatan keuangan yang belum dilakukan dengan baik, mengakibatkan tercampurnya harta pribadi dengan harta perusahaan, sehingga pelaku usaha tidak dapat melakukan monitoring terhadap arus keuangan usaha. Manajemen keuangan usaha kecil pada dasarnya tidak terlepas dari fungsi manajemen, yaitu meliputi kegiatan perencanaan/planning, pengorganisasian/organizing,

pelaksanaan/pengalokasian/actuating dan pengendalian/ controlling serta evaluasi (POAC). Rivai (2013) menyatan bahwa pencatatan laporan keuangan yang sistematis memiliki manfaat-manfaat, yaitu dapat memberikan informasi kas yang dapat dipercaya mengenai posisi keuangan usaha pada suatu saat tertentu, dapat memberikan informasi keuangan mengenai hasil usaha dalam satu periode akuntansi, dapat memberikan informasi-informasi yang dapat membantu pihak yang berkepentingan untuk menilai kondisi dan potensi suatu usaha serta dapat memberikan informasi penting lainnya yang relevan dengan pihak yang berkepentingan lainnya.

Kelurahan Mambok merupakan Salah satu wilayah/ Kelurahan di kota sintang yang lokasinya paling berdekatan dengan kampus STKIP Persada Khatulistiwa, di kelurahan mambok banyak pelaku Usaha Mikro, Kecil dan Mengah yang menggeluti berbagai bidang Usaha seperti warung makan, penjual sayur, warung sembako, pemilik kos, fotocopy, toko ATK dan masih banyak lagi jenis usaha lainnya, yang belum menerapkan secara penuh manajemen keuangan dan pembukuan pada usaha yang dijalankannya, selain itu pelaku Usaha mikro, kecil dan menengah di kelurahan mambok sudah memiliki kelompok yang tergabung dalam kelompok arisan pelaku usaha Mikro, kecil dan menengah dengan tujuan saling mendukung dalam kerjasama dan penggalangan dana antar sesama pelaku usaha. Sebagai masyarakat akademisi kami selaku tim pengusul kegiatan pengabdian ini merasa perlu untuk mendampingi kelompok masyarakat UMKM di kelurahan mambok dalam mengembangkan manajemen usaha agar dimasa yang akan datang usaha yang mereka jalankan semakin berkembang dan mendapat perhatian dari para pihak terkait sehingga memiliki keberlanjutan usaha dengan hasil lebih besar.

Berdasarkan latar belakang yang sudah diuraikan, maka salah satu solusi yang dapat diberikan adalah memberikan Training Manajemen Keuangan dan Pembukuan praktis bagi pelaku Usaha Mikro, Kecil dan 
Menengah kepada Pelaku UMKM di kelurahan Mambok Kabupaten Sintang.

Kegiatan PkM ini diharapkan memberikan kontibusi bagi pelaku UMKM dalam mengatur Manajemen keuangan yang baik. Pelaku UMKM dapat membuat pembukuan Praktis bagi usaha yang mereka jalankan. Meningkatkan keterampilan manajemen usaha bagi masyarakat dan menciptakan wirausaha yang mandiri berbasis Iptek.

\section{METODE PELAKSANAAN}

Metodologi pelaksanaan dalam pengabdian pada masyarakat ini dibagi menjadi 3 (tiga) tahap yaitu tahap awal, tahap pelaksanaan dan tahap akhir. Pada tahap awal dilaksanakan observasi, dan wawancara secara langsung dengan para pelaku usaha dan aparat pemerintah setempat seperti ketua RW dan pihak Kelurahan, hal ini bertujuan untuk mengetahui gambaran masyarakat setempat dan untuk mengetahui permasalahan/kendala yang dihadapi oleh pelaku usaha.

Tahap kedua adalah tahap pelaksanaan berupa: (1) Training Manajemen Keuangan, Pada tahap ini, peserta diberikan materi tentang Keputusan investasi (investment decision), Keputusan pendanaan (financing decision), dan Keputusan pengelolaan aset (assets management decision), dengan alat ukur konsep dasar dan penilaian capital budgeting; (2) pelatihan pembukuan keuangan praktis yang dapat diaplikasikan oleh pelaku usaha menengah, kecil dan mikro, hal ini bertujuan untuk meningkatkan keterampilan dan pengetahuan mengenai manajemen keuangan usaha agar tidak tercampur antara keuangan keluarga dengan keuangan usaha, melalui pencatatan keuangan pelaku usaha dapat mengetahui perkembangan usahanya.

Tahap yang terakhir adalah tahap monitoring. Pada tahap ini, dilakukan metode coaching, dimana para peserta pelatihan menunjukkan hasil pencatatan keuangannya dengan menceritakan hambatan dan kesulitan yang dihadapi dalam melakukan proses pencatatan. Selain pencatatan keuangan, para peserta pelatihan juga diharapkan membagi rencana strategis usaha dalam jangka waktu menengah untuk menunjukkan inovasi-inovasi yang akan dilakukan yang dapat meningkatkan daya saing usaha.

\section{HASIL DAN PEMBAHASAN}

Kegiatan Pengabdian masyarakat ini memberikan manfaat yang sangat berarti bagi pelaku UMKM di kelurahan Mambok Kabupaten Sintang. Peserta training memahami konsep manajemen keuangan bagi Usaha Mikro, kecil dan 
menengah yang sedang mereka jalankan.

Selain itu, peserta juga dapat membuat pencatatan atau pembukuan praktis atas transaksi yang terjadi dalam usahanya.

Peserta sudah dapat merumuskan tujuan jangka panjang dan jangka pendek yang harus dicapai dalam mengembangkan usahanya. Menyadari bahwa pencatatan keuangan itu penting untuk keberlangsungan usaha kedepan. Tim dosen pelaksana berharap agar para peserta yang hadir dapat konsisten melakukan memiliki perencanaan usaha ke depan yang lebih maju dan berkembang, sehingga pada akhirnya para pelaku usaha tersebut akan memiliki jumlah tabungan yang lebih besar demi meningkatkan kesejahteraan keluarga mereka serta memiliki pendapatan yang aktif. Selain itu, kegiatan ini juga diharapkan dapat memberikan alternatif pengembangan usaha yang dapat diaplikasikan oleh para pelaku usaha dalam menghadapi persaingan kedepan.

Selama pelatihan berlangsung, para peserta pelatihan terlihat begitu antusias dan sangat bersemangat, terbukti dengan banyaknya pertanyaan yang diajukan, baik pada sesi diskusi dan simulasi pengelolaan keuangan maupun pada sesi pembukuan praktis bagi UMKM. Para peserta tersebut juga menyatakan bahwa mereka tertarik untuk mencoba menerapkan metode pengelolaan keuangan yang telah dipaparkan serta membuat susunan jadwal yang teratur sesuai dengan jenis usaha dan dapat lebih semangat lagi dalam berwirausaha. Tim dosen pelaksana juga memberikan semangat dan motivasi agar para pelaku usaha dapat terus berkembang dengan usaha yang dijalaninya.

\section{Kontribusi kegiatan Pengabdian} Kepada Masyarakat ini bagi Kondisi keuangan dan bisnis pelaku usaha mikro kecil dan menengah di kelurahan mambok berdasarkan hasil monitoring dan evaluasi sebelum setelah kegiatan PKM dilakukan disajikan dalam tabel berikut:

\begin{tabular}{|c|c|}
\hline $\begin{array}{l}\text { Sebelum Kegiatan } \\
\text { Pengabdian Kepada } \\
\text { Masyarakat }\end{array}$ & $\begin{array}{l}\text { Setelah Kegiatan } \\
\text { Pengabdian Kepada } \\
\text { Masyarakat }\end{array}$ \\
\hline $\begin{array}{l}\text { Para pelaku UMKM kurang } \\
\text { memiliki semangat dalam } \\
\text { berwirausaha serta masih } \\
\text { memiliki kemampuan yang } \\
\text { terbatas dalam mengelola } \\
\text { keuangan. } \\
\text { a. } \\
\text { Para peserta } \\
\text { menyatakan } \\
\text { bahwa dalam } \\
\text { setiap harinya } \\
\text { banyak penge- } \\
\text { luaran tidak } \\
\text { terduga yang } \\
\text { membuat ibu-ibu } \\
\text { tersebut harus } \\
\text { mengambil uang } \\
\text { simpanan yang } \\
\text { seharusnya } \\
\text { menjadi } \\
\text { tabungan }\end{array}$ & $\begin{array}{l}\text { Para pelaku UMKM } \\
\text { mendapatkan pengetahuan } \\
\text { mengenai cara mengelola } \\
\text { keuangan mereka dengan } \\
\text { baik melalui sebuah } \\
\text { simulasi, ditambah dengan } \\
\text { berba-gai tips, seperti: } \\
\text { Anggaran belanja dibuat } \\
\text { per bulan dan bukan } \\
\text { harian, teruta-ma untuk } \\
\text { kebutuhan primer, } \\
\text { seperti semba-ko (beras, } \\
\text { minyak goreng, gula } \\
\text { pasir), bensin, dan } \\
\text { kebutu-han mandi. } \\
\text { sudah dapat } \\
\text { merumuskan tujuan } \\
\text { jangka pendek dan } \\
\text { jangka panjang yang } \\
\text { ingin mereka wujudkan }\end{array}$ \\
\hline
\end{tabular}




\begin{tabular}{|c|c|c|}
\hline c. & $\begin{array}{l}\text { mereka, misalnya } \\
\text { untuk keperluan } \\
\text { pergi ke acara } \\
\text { undangan } \\
\text { pernikahan, ada } \\
\text { anggota keluarga } \\
\text { yang sakit, dan } \\
\text { jajan anak yang } \\
\text { sering-kali tidak } \\
\text { terkontrol. } \\
\text { Belum } \\
\text { menetapkan } \\
\text { target usaha yang } \\
\text { ingin dicapai } \\
\text { Kesulitan } \\
\text { mendapatkan } \\
\text { kredit atau } \\
\text { sumber dana } \\
\text { untuk } \\
\text { pengembangan } \\
\text { usaha dari } \\
\text { lembaga } \\
\text { keuangan }\end{array}$ & $\begin{array}{l}\text { dari usaha yang sedang } \\
\text { dijalankan. } \\
\text { pelaku usaha sudah } \\
\text { dapat membuat } \\
\text { pembukuan dan laporan } \\
\text { keuangan yang rapi, } \\
\text { sebagai langkah awal } \\
\text { menertibkan keuangan } \\
\text { usaha dan modal untuk } \\
\text { memperoleh } \\
\text { kepercayaan dari } \\
\text { lembaga keuangan atau } \\
\text { penyalur kredit usaha. }\end{array}$ \\
\hline
\end{tabular}

\section{SIMPULAN}

Berdasarkan hasil pelaksanaan kegiatan yang telah dilakukan, maka terdapat beberapa hal yang dapat disimpulkan dari kegiatan Pengabdian Pada Masyarakat (P2M) ini, yaitu:
1. Pengetahuan dan pemahaman peserta pelaku usaha kecil dan binaan koperasi masih rendah terkait dengan semangat berwira-usaha dan bagimana mengelola keuangan

2. Pelatihan yang dilaksanakan mampu meningkatkan jiwa wirausaha dan motivasi para pelaku usaha dalam menjalankan usaha bisnisnya dengan baik dan optimal.

\section{REFERENSI}

Halim, Abdul. 2007. Manajemen Keuangan Bisnis. Ghalia Indonesia, Bogor

Wedyawati, Nelly. 2017. Panduan

Pelaksanaan Pengabdian pada Masyarakat.

Rivai, V. 2013. Commercial Bank ManageMent: Manajemen Perbankan Dari Teori Ke Praktik. Edisi 1.Cetakan 1. Jakarta: Rajawali Pers. 